\title{
Swedish politicians preferences regarding the privatisation of elderly care
}

\author{
Ming Guo and Sam Willner \\ Journal Article
}

Tweet

N.B.: When citing this work, cite the original article.

This is an electronic version of an article published in:

Ming Guo and Sam Willner, Swedish politicians preferences regarding the privatisation of elderly care, Local Government Studies, 2017. 43(1), pp..

Local Government Studies is available online at informaworldTM:

http://dx.doi.org/10.1080/03003930.2016.1237354

Copyright: Taylor \& Francis (Routledge): SSH Titles

http://www.routledge.com/

Postprint available at: Linköping University Electronic Press

http://urn.kb.se/resolve?urn=urn:nbn:se:liu:diva-133721

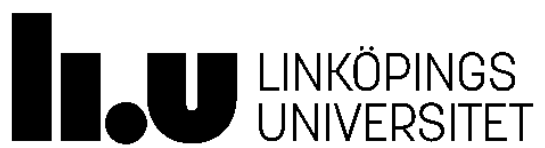




\title{
Swedish politicians' preferences regarding the privatisation of elderly care
}

\begin{abstract}
:
Since the 1990s, Sweden has embarked on a series of market reforms in public services, aiming for greater efficiency and better service quality. Nevertheless, the political debates do not seem to fade away and local politicians still have to decide on privatisation issues. We argue that attitude studies of local politicians are of importance and present a 2014-survey in this regard, using Swedish elderly care as one example. Our findings show that attitudinal difference between left- and right-wing politicians on private for-profit providers remains. Moreover, political orientations of individuals, political majority in the municipality, as well as privatisation level already achieved locally are identified as important factors in explaining local politicians’ willingness to privatise further. This case study serves as a good example to examine the market development of public welfare in advanced welfare states and also contributes to the contentious discussion of political roles in welfare reform.
\end{abstract}

Key Words: Elderly care, politicians, preference, marketisation, privatisation, Sweden 


\section{Introduction}

Since the 1980s, neo-liberal ideas such as New Public Management (NPM) have gained momentum and begun to prevail in North America and Western Europe (Megginson and Netter 2001). Many Western welfare states, including Sweden, have increased their use of privatisation in the public sector (Green-Pedersen 2002; Blomqvist 2004). This use of market mechanisms to deliver care is one of the most significant and contentious ways in which welfare states have been transformed (Gilbert 2002).

Despite the lack of consensus as to what exactly NPM is, proponents of this line of thinking often view it as a management for all seasons (Hood 1991; Manning 2001). Their core assumption is that the public sector is inherently inferior to the market in its capacity to produce cost-efficient services and that it fails to satisfy citizens’ demands (Hood 1991; Kettl 1993). NPM scholars also believe that the decentralisation of power is necessary for empowering lower-level units to some degree of autonomy, and recommend lower tax, competition and privatisation (Young 2000).

Under the influence of liberal thinking such as NPM, and prompted by economic crisis, many governments have begun to privatise elements of the public sector, including health care, education and social care. In fact, elderly care was the first area of social services to be transformed into a welfare market in the 1990s. It is about two and a half decades since Sweden introduced the market to elderly care provision. We are interested in looking at how local politicians view market-related issues, and if there are any, the differences that remain among them regarding welfare attitude. For the purpose of this study, we focus on elderly care privatisation in Sweden. As one prime type of welfare state (Esping-Andersen 1990), Sweden offers a good example to analyse the relation between policy makers and market influence. Therefore, our research objective here is to explore the attitude pattern of local 
politicians and expand our understanding of possible contributing factors to preferences shaping.

This article is organised as follows: in the next section, we first present the Swedish case in elderly care privatisation, including its local political structure responsible for elderly care. Then we review the literature regarding attitudes toward privatisation of public services. Next, our national survey study results are displayed with several regression models focusing on the explanation of preference shaping discussed. To be more specific, we try to answer the following questions: what are the predominant individual factors that could account for local politicians' private provider preference and to what extent? What are the important factors on a local level? What role does political orientation play in shaping local politicians' attitudes on public or non-profit care providers? Finally, we conclude with discussions of the importance of political ideology in welfare reforms.

The case of Swedish elderly care

The Local Government Act of 1992 enabled local municipalities to outsource the provision of tax-financed care services to non-governmental actors - both for-profit and non-profit organisations. Since then, an increasing share of publicly financed elderly care has been run by private providers (Szebehely 2011). Over the decades, the process of privatisation has continued. The proportion of home care services and residential care provided by private entrepreneurs has increased from 4\% and 5\% respectively in 1993, to 10\% and 14\% in 2005 and further to 24\% and 21\% in 2013 (Erlandsson et al. 2013; NBHW 2014).

Compared with other advanced welfare states, there are some characteristics of elderly care privatisation that are particular to Sweden. First, the private sector is at present largely dominated by a few big for-profit companies, and nearly $96 \%$ of the workforce in the private home care sector and $85 \%$ in the private residential living sector for elderly people 
were employed by for-profit companies in 2010 (Szebehely 2011). Second, the share of nonprofit organisations is quite modest in the provision of elderly care services: accounting for 3\% of the workforce (Johansson, O. 2011) and mainly in home care services (Konkurrensverket 2013) ${ }^{1}$. Third, the development of the market in elderly care varies between municipalities. In 2013, roughly two-thirds of all municipalities had no or less than $5 \%$ of their residential living or home care services provided by the private sector, while around 20 municipalities had more than $50 \%$ of their institutional housing provided privately (NBHW 2014). Moreover, the extent of privatisation is particularly great in densely populated municipalities in the Stockholm area, while private providers of elderly care are far less numerous in small and sparsely populated municipalities. Irrespective of privatisation, Swedish elderly care is still largely financed by taxes (NBHW 2007) ${ }^{2}$, which also sets Sweden apart from systems where individuals have to mostly make out-of-pocket payments to access care.

Some of the major arguments deployed by the proponents for initiating the marketisation process echoed the NPM, and insisted that market competition would lead to reduced costs and improved quality, as well as increased freedom of choice for care users. This logic is also present in local outsourcing with non-profit organisations, which is characterised by its service accountability, professionalism and community legitimacy for instance (Feiock and Jang 2009). The real effects are, however, debatable (Meagher and Szebehely 2013).

\section{Local politics and politicians in Sweden}

Sweden used to have a stable two-bloc political system (Elinder 2010) ${ }^{3}$ : The left-green bloc includes the Left Party (V), the Social Democratic Party (S) and the Green Party (MP). The centre-right bloc, Alliansen, is composed of the Moderates (M), the Centre Party (C), the Liberal Party (FP) and the Christian Democrats (KD). This pattern has gradually changed 
because of the emergence of Sweden's Democratic Party (SD) ${ }^{4}$. As of spring 2014, 108 out of a total of 290 municipalities were governed by centre-right parties, 107 by left-green parties, and 75 by coalitions between left and right (SKL 2015).

At the local level, all 290 local municipalities are obliged to provide residential and home care services for elderly citizens. Local politicians are democratically elected and are responsible for local issues. Usually, specific committees consisting of local politicians, the Äldrenämnden (elderly board) for example, are responsible for decision-making. There are both full-time, professional politicians and part-time ones at the local level. Most elected politicians devote a certain amount of time to local politics and often have another daytime job. They face elections every 4 years, the same as central government politicians.

As mentioned above, it is arguable that NPM or even political pragmatism might have had an impact on public welfare organisation and market regulation ${ }^{5}$. If we look retrospectively at the Swedish case, it was the Social Democrats who initiated elderly reform, which then paved the way for further privatisation in the 1990s. From a theoretical perspective, the New Politics of the Welfare State (NP) emphasises the importance of policy structures, institutions and vested interests, asserting that faced with challenges such as an aging population and budget limits, there is no room for partisanship in decisions over welfare policies in the 'era of austerity' ${ }^{\prime 6}$ (Pierson 1996, 2001). One consequence is that local politicians are more likely to reduce public welfare burdens and encourage private provision (Ferris and Graddy 1986; Savas 2000).

There are other factors to take into consideration while explaining specific policy choice as well. For instance, based on the 'Downsian' model (Hansen, Palfrey, and Rosenthal, 1987), it is argued that both left- and right-wing politicians will converge on welfare policies that appeal to the majority of voters. Blame avoidance strategies are also 
considered to be the only solution: the only way of retrenching without losing votes is to hide the fact that politicians are doing it (Weaver 1986; Pierson 2001; Hering 2008). Pierson (1994) also argues that politicians must pursue strategies of obfuscation and division when dealing with the unpopular politics of welfare retrenchment. These arguments make it more interesting to look at what politicians would prefer to do before they adopt the strategies above.

\section{Attitudes toward privatisation of public services}

Belief systems in general and attitudes to the welfare state, in particular, are known to be complex and extend to more than one dimension (Converse 1964; Zaller 1992). Many locallevel studies discuss privatisation without paying attention to attitudinal aspects (Fredriksson et al. 2010). There are fewer studies on politicians and partisan welfare preferences than on public opinions (Johansson Sevä 2010; Edlund and Johansson Sevä 2013) and even in the Nordic context (e.g. Sörensen and Bay 2002; Fredriksson et al. 2010; Gilljam, Karlsson and Sundell 2010). Some scholars assume that research focusing on the attitudes to welfare of ordinary citizens will also give some insights on the factors influencing the attitudes of local politicians. However, it should be acknowledged that voters and politicians might have different views in some respects (Ågren, Dahlberg, and Mörk 2007) and that the factors affecting public opinion and politicians’ preferences might not be the same.

Up until quite recently, individual characteristics, such as age, gender and socioeconomic background have often been the prime focus in welfare state attitudes studies. On an individual level, it is commonly suggested that self-interest and norm-shaping are the most important explanatory mechanisms linking specific conditions to attitudinal outcomes (Blomberg and Kroll 1999; Johansson Sevä 2009). Past literature also indicates that socioeconomic factors such as social class and occupation play a major role in shaping preferences 
(Svallfors 1989, 2004; Edlund 2006). For instance, public sector employees are more positive to public welfare provision compared with people working in the private sector (Sørensen and Bay 2002; Edlund 2006). Individuals on lower incomes or with lower education also tend to be more supportive of public welfare (Blomberg and Kroll 1999; Svallfors 1989).

Politicians' political orientation could reflect their belief system as well as the influence they have received from party socialisation. The classification of left or right reflects an ideological divide, which could serve as a clue for discerning opinions on privatisation and outsourcing. Left-wing parties are traditionally pro-government and aimed at egalitarian policies while right-wing parties favour market solutions and less government intervention (e.g. Bobbio 1996; Sørensen and Bay 2002; Mair 2007; Fredriksson et al. 2010; Dahlberg and Lundqvist 2013).

Regarding age, some studies claim that older people are often more positive towards public welfare (e.g. Blekesaume and Quadagno 2003; Jaeger 2006; Edlund and Johansson Sevä 2013) and critical about competitive tendering (Sørensen and Bay 2002). Others claim that attitudes are characteristic of certain cohorts or generations rather than age per se, suggesting that attitudes or norms are shaped by major societal events, such as economic crises, progress, or political change, during an individual's formative years (Becker 1990; Inglehart 1971; De Vries 2005) ${ }^{7}$. Regarding gender, several studies have shown that women tend to be more supportive of public welfare than men because of differences in self-interest and gender-related norms (e.g. Svallfors 1989; Blomberg and Kroll 1999; Blekesaune and Quadagno 2003; Jaeger 2005).

Among politicians, the position within the political system might affect their attitudes. For instance, according to May’s law (e.g. Norris 1995), party politicians in top positions tend to be less radical than politicians at a lower level. One reason for this is that politicians 
who are directly responsible for actual policy decisions (in a higher position or representing the governing majority) might be inclined to be more cooperative and take less radical positions than politicians who do not have a direct political responsibility. Gilljam, Karlsson, and Sundell (2010) tested May’s law and showed that powerful leading politicians tended to adopt more right-wing attitudes in general, irrespective of their political orientation. Leadership takes place within institutions and so power distribution, rules and roles help to define leadership choices and affect preferences.

Several studies analyse the direct impact of contextual factors - such as public policy, political climate and socio-economic conditions - on attitudes on public welfare. For instance, Blomberg and Kroll (1999) found that poor economic conditions, a low level of social and health expenditures, and a dominance of bourgeois parties was associated with a lower support among ordinary citizens for public welfare services in Finland. Johansson Sevä (2009) found a more supportive attitude toward public welfare prevalent in Swedish municipalities characterised by social problems. Regarding political majorities, contentious results were found (see for instance Søren 2003; Jensen and Lolle 2013). Stolt and Winblad (2009) suggested that metropolitan areas dominated by left-wing parties are still subject to the influence of neighbouring municipalities in their willingness to see the share of privatisation introduced or increased, irrespective of political orientation. However, conclusions about the less important role of the local political majority remain moot. In addition to these macro-level factors, local institutional conditions, such as local public service privatisation, could also affect preferences regarding service delivery (Rothstein 1998). Some studies have also shown that factors such as population density, taxation powers, educational level and geographical proximity are associated with the degree of privatisation in various municipalities (Sørensen and Bay 2002; Stolt and Winblad 2009; Jensen and Lolle 2013). 


\section{Methods and data collection}

We designed an online survey to test our hypothesis and answer several related research questions. By using SurveyMonkey ${ }^{\circledR}$, a survey link was sent to local politicians responsible for elderly care in Swedish municipalities ${ }^{8}$ by email. All survey questions were laid out in Swedish to facilitate response, and one general reminder was sent 1 month afterwards. We collected data between December 2013 and August 2014, before the 2014 national election on $14^{\text {th }}$ September. A total number of 3,340 online survey question samples were sent out, and 1,362 were considered as valid replies, yielding a response rate of $41 \%$. Responses came from 238 municipalities out of 290. Background information about the politicians can be found in Appendix 1.

Attitudes towards privatisation in elderly care were investigated by asking the respondents about their preferences for more or less private provision in their home municipality, as well as by asking for their view about the optimum share of private forprofit/non-profit/public provision in elderly care. All survey questions used can be found in Appendix 2.

Regarding modelling, independent and dependent variables are shown in Table 1. Independent variables included in our survey cover major explanatory factors mentioned in previous studies (except income) ${ }^{9}$. Individual variables include age, gender, party affiliation, political position and terms served. Contextual factors include the political majority in spring 2014 (as an example of institutional factors), whether the politicians are located in Stockholm (geographical proximity), population density and taxation powers as well as privatisation level. We use the average of hours of home care by private providers and percentage of private providers in institutional living to generate local privatisation level.

\section{Results}


1. Descriptive data about preference over private/public care provision.

As shown in Table 2, there are substantial differences between the political blocs regarding preferences for more or less private providers in their municipality ${ }^{10}$. Only $2 \%$ of left-wing politicians wanted more private care, compared with nearly $70 \%$ of right-wing politicians. On the other hand, $58 \%$ of left-wing politicians favoured less private care, while only $2 \%$ of right-wing politicians believed the same. Furthermore, there were also some substantial differences within the blocs. The Left Party politicians were the most critical towards private care in the left bloc, and the Moderate Party were most affirmative in the right bloc. Both left- and right-wing politicians do not converge in their preference for private care provision.

Regarding the optimum share of private/public care provision, the left bloc prefers an 85/15 share of public/private providers, while the right bloc a 50/50 (Table 3). Preferences for profits also varied significantly between the two blocs: the right-bloc parties are more supportive of for-profit provision, especially the Moderates (36.96\%) whereas the left-wing parties are just the opposite. About private non-profit providers, the Green Party politicians express a more positive attitude in the left bloc, even more so than most right-wing parties, except for Christian Democrats.

\section{Theoretical modelling}

After showing the distinct partisan approach to privatisation, we now use logistic regression models to examine how different individual and contextual factors might have influenced preference shaping (Table 4) and conduct ordinary least-squares (OLS) regressions (shown in Table 5) ${ }^{11}$.

Table 4 presents models of willingness to have more private providers in the politicians’ municipalities. Model 1 includes only several individual factors, and political orientation is shown to be of great significance, whereas age, gender and other individual 
attributes do not affect the preference shaping. Privatisation level already in local municipality might also influence attitude and we chose to include it into Model 2 and Model 4. Model 2 shows both political orientation and local privatisation as significant covariates. Note that the general fitness of regression model decreases as the Hosmer-Lemeshow test significance drops from 0.931 to 0.605 . Model 3 covers both individual level and municipality level factors, excluding degree of privatisation for the moment. The significance result suggests that political orientation and majority are two important factors that could account for the preference dependent variable. Taking degree of privatisation into consideration, Model 4 shows that three covariates are statistically significant: political orientation, the majority and privatisation level. To be more specific, right-wing political orientation is positively associated with preference for more private providers, whereas rightwing majority and a higher degree of local privatisation negatively affect the preference.

Table 5 presents the results of the preferences using multiple regression models ${ }^{12}$. We divide the preference for private into two subcategories: for profit and non-profit. The regression results show that age, gender and political orientation on an individual level are important factors to explain for-profit provider preference. Age, on the other hand, is negatively associated with preference: the older group (over 50 years old) is more negative about choosing private-for-profit providers to deliver elderly care. Female politicians are also more sceptical about private providers. Positions and served terms do not seem to matter. At the municipality level, our model shows that political majority is negatively associated with private-for-profit preference: right-wing dominated municipalities tend to accompany negative views about private-for-profit providers.

As the coefficient of determination $\left(\mathrm{R}^{2}\right)$ is quite low in the model for non-profit providers, we remain cautious about the interpretations. Similar to the previous model for forprofit, political orientation and gender seem to be important individual factors. Regarding 
other contextual factors, Stockholm area appears to be associated with a positive attitude to non-profit providers whereas higher population density is likely to influence the attitude negatively.

Regarding public provider preference, we notice that political orientation, privatisation level and a local government majority are important factors. Furthermore, older age is positively linked with positive public provider preference, similar to previous study results. Although higher population density favours a preference for public providers, population size (in the log) in general is negatively associated with more public provision, suggesting that the higher the population, the more likely is support for various provisions.

To sum up, right-wing politicians, especially male ones, tend to favour more for-profit as well as non-profit care providers, and younger politicians are more favourable to for-profit private ones. A right-wing political majority in the municipality, as well as a relatively higher privatisation level already achieved locally, is likely to restrict local politicians' willingness to privatise further.

\section{Discussion}

The above analysis displays a substantial difference between local politicians from two political blocs regarding their preference for elderly care privatisation. Descriptive statistic data show that not only left- and right-wing politicians embrace various service providers to a different extent, but also reveal the distinctive attitude pattern for private for-profit providers: $1.23 \%$ from the left versus $30.76 \%$ from the right. On the one hand, this could result from distinct political orientation and policy goals. On the other hand, the reason for this distinct preference lies in the fact that the Swedish elderly care system is tax-funded and some political parties are critical about making profits out of the publicly funded system. 
Therefore, a debate about ownership is more likely to be transferred into a debate revolving around profit-making and public funding.

Based on our regression models (both in Table 4 and Table 5), political factors are important and could account for attitude pattern. On an individual level, political orientation is positively associated with private provider preference and resources that should be distributed in. This result might not be surprising, considering what traditional partisanship theory claims: the right-wing politicians embrace more neoliberal, market-oriented solutions compared with their left-wing counterparts. Thus, the diminishing influence of the political orientation argument is questionable. We can even conclude that Swedish local politicians’ preferences for private providers appear to be due in large part to their political orientation, which also interacts with non-political factors such as belief in family values or religion.

It is somewhat surprising to see that political majority negatively influences the private provider preference: a right-wing dominated local government is more likely to be associated with negative preferences for private providers (Table 4). Why does political majority at municipality level play in a negative way? We offer some attempted explanations here. First, a compromise argument: right-wing politicians in charge of government might be more pragmatic and are willing to compromise, which makes their attitudes less radical, compared to when they are in opposition (Gilljam and Karlsson 2015). Second, blame avoidance: political parties in the majority are more careful about pushing forward more drastic market reforms, which they will be held responsible for. Third, more privatisation also tends to weaken the basis for political control as it reduces the local authority's scope for exerting influence ${ }^{13}$. We remain open to the discussion of the political majority, as the interaction between local government majority and minority might be both dynamic and complex. 
Regarding non-profit provider preference, our analysis also confirms the importance of political factors as shown by other studies (Feiock and Jang 2009; Warner and Hefetz 2012). In the Swedish context, the very nature of the public funding system might compel local politicians, as gatekeepers of the welfare system, to be stricter about market entry conditions for providers. Smaller and less populated areas might have limited capacity to build up a public care system. In this regard, the introduction of a customer-choice (voucher) system seems both feasible and favourable as the system only relies on elements of market competition and can still provide publicly subsidised care without limiting user choice. Indeed, a marked increase in numbers of non-profit providers of social services has been noticed after the introduction of a voucher system in several other countries (Warner and Gradus 2011).

Privatisation level is another significant covariate in our findings, which is measured as an average of both home services hours and special housing provided by private providers. As shown in Table 4, the addition of this index seems to lower the fitness of the model, which compels us to test other alternative independent variables. For instance, if we use the percentage of private nursing homes for Model 4, the Hosmer-Lemeshow test significance will increase from 0.38 to 0.809 , which suggests that this new measurement of privatisation level is a better one.

Table 4 also shows that the actual privatisation level will likely negatively affect the expressed preferences for more private elderly care in one’s municipality. This seemingly intriguing result could possibly be interpreted in different ways: first, for some municipalities, it becomes impossible to increase the share of private providers if the private sector already runs $100 \%$ of elderly care. Second, a rather tempting explanation is that local politicians might be aware of the limitations of the market solution and therefore do not want to speed up the privatisation process, which could also explain the relatively low degree of 
privatisation nationwide (around 21\% regarding home services and nursing homes). A third explanation is that municipalities in rural areas are less attractive to private providers because of the smaller market and less potential business profits. To sum up, the causal relationship between political orientation and level of privatisation in a municipality is hard to determine based on our data. The question could be simplified by asking to what extent political factors account for the degree of privatisation, both on an institutional and on an individual level.

\section{Conclusion:}

We started from an assumption that Swedish local politicians, who have been heavily influenced by neoliberal ideas such as NPM and even pragmatism for over three decades, might embrace more market solutions and are therefore more positive about using private care providers to provide social welfare. Our survey result presents another picture: local politicians’ preferences still diverge between political blocs, with left-wing politicians being more cautious about private, for-profit care providers compared with their counterparts in the right-wing bloc, as shown in Table 2 and Table 3. Local politicians are still, to a large extent, driven by their political orientation in engaging with issues of privatisation. In this sense, the old conceptualisation of left and right is still useful as a simple marker for identifying market preferences.

Past literature shows that personal factors such as age, gender and socio-economic factors could shape welfare attitude. Among the contributing factors that we investigated, the political affiliation of the individual, as well as the political majority and the degree of privatisation already present in their home municipality, were identified as the most important factors in explaining the distinct preferences for private for-profit care providers. This finding is in line with previous studies (Bel and Fageda 2007; Hefetz and Warner 2012) 
and reminds us of the importance of contextual factors in shaping not only politicians’ preferences but also in explaining the various level of privatisation across municipalities.

As mentioned before, the elderly care markets in Swedish municipalities are not shaped homogeneously, nor will they develop at the same pace. Markets in public services do not operate uniformly, even under the same welfare state framework (Esping-Andersen 1990). All these make local politicians an important part in elderly care provision and as gatekeepers monitoring the process. In reality, politicians across the political spectrum face different incentives to reform welfare services, and they are not always able to demonstrate their personal preferences clearly in real political life, which gives us another reason not to turn our attention away from local politicians.

The New Politics perspective proposed that there has been a decline in party polarisation over redistributive issues since the 1970s and argued the diminished importance of partisanship in welfare policy shaping. Empirically speaking, our data here alone is not sufficient to fully test this thesis, and Lindbom (2014) argues that the NP thesis might be too complicated to test fully. Furthermore, we are also aware that there might be some missing gaps in the belief system and real policymaking process.

The question of public ownership has always been at the centre of the left-right divide: the left-wing socialist parties insist on using the means of nationalised production to distribute welfare resources while the right-wing tends to favour more private for-profit care providers by encouraging entrepreneurship and pursuit of profit. Our case study goes a step further by showing a more diversified pattern of local politicians’ market preferences in elderly care and highlights the tension between the public funding system and profit making in the market. 
The influence of political ideology, despite three decades of privatisation practice or the strong influence of NPM, still plays a major role in shaping market-relevant attitudes. The rise of market reform does not mark an end to traditional theories of the welfare state, nor does it suggest the non-political feature of privatisation. It could be argued further that in fields that tend to be more politicised, such as health care or school education, the strong influence of political ideology might also prevail.

Due to space constraints, variances within each political bloc have not been shown in this article - a topic worthy of development in the future. Meanwhile, we remain open to the suggestion of other plausible explanations for the formation of the attitudes discussed here, since there might be other personal or contextual factors that could shape an individual politician's attitude towards privatisation. Last but not least, patterns of partisan ideology and politicians’ preferences are worth monitoring as they might change over time and space. 


\section{Notes}

1. The reason for the relatively small share of elderly care provided by the non-profit sector is elusive. One explanation could be that Sweden has a strong public sector and activities from non-profit organisations have been performed and organised in ways such as through volunteering (Konkurrensverket 2013).

2. $82-85 \%$ of the total cost is covered by local tax, $10 \%$ by national tax and $5-6 \%$ by the elderly themselves. This was a more general description of funding for elderly care in Sweden. To our knowledge, more detailed data on municipality level is not available yet.

3. This was true on the national level. During our survey period, the previous election had been held in 2010 and the Centre-right bloc was in charge of the national government.

4. Sweden's Democrats got $13 \%$ of the votes in the 2014 national parliamentary elections. However, SD is normally positioned outside of these two blocs and neither left- or right- wing parties are willing to cooperate with them in the parliament.

5. Ormerod (2006) once pointed out that pragmatism is a theory about meaning, characterised by weak values and uncertain cognitive frameworks. By contrast, ideology is marked by strong values and firm cognitive systems. Regarding political pragmatism, there are no abstract principles such as individual liberty, freedom, equality or beliefs about the market economy for the development of society. 
Ideological politics, on the contrary, is embedded with belief systems full of principles, normative ideals and other cognitive frameworks.

6. The usage of austerity is connected with slow economic growth, rising deficits, high levels of unemployment and so on. There is no obvious fiscal austerity in Sweden now. Nevertheless, we use austerity here in a similar sense as opposed to welfare expansion, c.f. Pierson (2001) and Lindbom (2016).

7. There are, however, studies showing that support for public welfare measures may vary among different age groups depending on the type of welfare area, see for instance Svallfors (1999).

8. We conducted a pilot study first, which served as a basis for redesigning and revising the questionnaire. From the beginning of March 2014, we sent a request to all Swedish municipalities, based on the information provided by the Swedish Association of Local Authorities and Regions (Sveriges Kommuner och Landsting, SKL) asking for their cooperation and consent to participate in the survey.

9. Our survey did not include questions about personal education, background or income level. We wanted to avoid any intrusion of privacy and concomitant low response rate. Admittedly, these personal data would have been helpful in further explaining the variances in politicians' attitudes.

10. Those choosing not to express their opinion regarding preferences for private or public providers (circa 2\%) have been removed from the analysis.

11. No multicollinearity of independent variables was detected in the regression analysis.

12. Regarding our second dependent variable, namely, the optimal distribution of private/public providers, we have to admit that such a perfect point might not actually exist in the economic models because of externalities, multiple principals and information asymmetries (Hindriks and Myles 2006; Barr 2012). For analysis 
purposes, we used the Huber-White method, which avoids the need for assumptions of normal distribution and homoscedasticity to fit data.

13. We had one probing question in our survey (not shown in this article) and the result shows that politicians, irrespective of political orientations, share the same view that the level of transparency and political overseeing of the system should be increased. 


\section{References:}

Ågren, H., M. Dahlberg, and E. Mörk. 2007. “Do Politicians’ Preferences Correspond to Those of the Voters? An Investigation of Political Representation.” Public Choice 130 (1): 137-162. doi: 10.1007/s11127-006-9077-1.

Barr, N. 2012. The Economics of the Welfare State. Oxford: Oxford University Press.

Becker, H. A. 1990. Dynamics of Cohort and Generation Research. Amsterdam: Thesis Publishers.

Bel, G., and X. Fageda. 2007. "Why do local governments privatise public services? A survey of empirical studies.” Local Government Studies, 33(4), 517-534.

Blekesaume, M., and J. Quadagno. 2003. "Public Attitudes toward Welfare State Policies: A Comparative Analysis of 24 Nations.” European Sociological Review 19 (5): 415427. doi: 10.1093/esr/19.5.415.

Blomberg, H., and C. Kroll. 1999. “Do Structural Contexts Matter? Macrosociological Factors and Popular Attitudes towards Public Welfare Services.” Acta Sociologica 42 (4): 319-335. doi: 10.1177/000169939904200403.

Blomqvist, P. 2004. “The Choice Revolution: Privatisation of Swedish Welfare Services in the 1990s.” Social Policy \& Administration, 38(2): 139-155. doi: 10.1111/j.14679515.2004.00382.x

Bobbio, N. 1996. Left and Right: The Significance of a Political Distinction. London: Polity Press.

Converse, P. 1964. “The nature of belief systems in mass publics.” In Ideology and Discontent, edited by D. Apter, 206-261. New York: Wiley. 
Dahlberg, M., and H. Lundqvist. 2013. "Politikers egenskaper och privatisering av välfärdstjänster.” [Politicians’ Attributes and Privatisation of Welfare Services]. In: Välfärdstjänster i privat regi: Framväxt och drivkrafter [Welfare Services in Private Enterprises: Growth and Incentives], edited by H. Jordahl, 165-188. Stockholm: SNS.

De Vries, M. S. 2005. "Changing Policy Views at the Local Level: The Effect of Age, Generations and Policy-Periods in Five European Countries.” European Journal of Public Research 44 (1): 1-15. doi: 10.1111/j.1475-6765.2005.00216.x.

Edlund, J. 2006. "Trust in the Capability of the Welfare State and General Welfare State Support: Sweden 1997-2002.” Acta Sociologica 49 (4): 395-417. doi: 10.1177/0001699306071681.

Edlund, J., and I. Johansson Sevä. 2013. “Is Sweden Being Torn Apart? Privatization and Old and New Patterns of Welfare State Support.” Social Policy \& Administration 47 (5): 542-564. doi: 10.1111/spol.12021.

Elinder, M. 2010. “Local Economies and General Elections: The Influence of Municipal and Regional Economic Conditions on Voting in Sweden 1985-2002.” European Journal of Political Economy 26 (2): 279-292. doi: 10.1016/j.ejpoleco.2010.01.003.

Esping-Andersen, G. 1990. The Three Worlds of Welfare Capitalism. Cambridge: Polity. Erlandsson, S., P. Storm, A. Stranz, M. Szebehely, and G-B. Trydegård. 2013. "Marketising Trends in Swedish Eldercare: Competition, Choice and Calls for Stricter Regulation.” In Marketisation in Nordic Eldercare: A Research Report on Legislation, Oversight, Extent and Consequences, edited by G. Meagher and M. Szebehely, 23-75. Stockholm: Stockholm University.

Feiock, R. C., and H. S. Jang. 2009. “Nonprofits as Local Government Service Contractors.” Public Administration Review, 69(4), 668-680. doi:10.1111/j.15406210.2009.02016.x 
Ferris J., and E. Graddy. 1986. “Contracting Out: For What? With Whom?” Public Administration Review. July/August: 322-343.

Fredriksson, S., H. Olli., M. Mattila., and H. Wass. 2010. “The Politics of Competitive Tendering: Political Orientation and Attitudes towards Contracting Out among Finnish Local Politicians.” Local Government Studies 36 (5): 637-654. doi: 10.1080/03003930.2010.506977.

Gilbert, N. 2002. Transformation of the Welfare State: The Silent Surrender of Public Responsibility. Oxford, UK: Oxford University Press.

Gilljam, M., D. Karlsson, and A. Sundell. 2010. Politik på hemmaplan: tiotusen fullmäktigeledamöter tycker om politik och demokrati [Ten Thousand Councillors Deliberate on Politicis and Democracy]. Stockholm: SKL Kommentus.

Gilljam, M., and D. Karlsson. 2015. “Ruling Majority and Opposition: How Parliamentary Position Affects the Attitudes of Political Representatives.” Parliamentary Affairs, 68, $555-572$.

Green-Pedersen C. 2002. "New public management reforms of the Danish and Swedish welfare states: the role of different social democratic responses.” Governance, 15 (2): $271-294$.

Hansen, S., T. R. Palfrey, and H. Rosenthal. 1987. “The Downsian Model of Electoral Participation: Formal Theory and Empirical Analysis of the Constituency Size Effect.” Public Choice (52): 15-33.

Hefetz, A., and M. Warner. 2012. “Contracting or public delivery? The importance of service, market and management characteristics.” Journal of Public Administration Research and Theory, 22(2), 289-317. 
Hering, M. 2008. "Welfare state restructuring without grand coalitions: the role of informal cooperation in blame avoidance.” German Politics, 17, 165-183. doi:10.1080/09644000802075757

Hindriks, J., and G.D. Myles. 2006. Intermediate Public Economics. Cambridge, Mass.: MIT Press.

Hood, C. 1991. “A PUBLIC MANAGEMENT FOR ALL SEASONS?” Public Administration, 69(1), 3-19. doi: 10.1111/j.1467-9299.1991.tb00779.x

Inglehart, R. 1971. “The Silent Generation: Intergenerational Change in Post-Industrial Societies.” American Political Science Review 79: 97-116.

Jaeger, M. M. 2005. “Welfare Regimes and Attitudes Towards Redistribution: The Regime Hypothesis Revisited.” European Sociological Review 22 (2): 157-170. doi: 10.1093/esr/jci049.

Jæger, M. M. 2006. “What Makes People Support Public Responsibility for Welfare Provision: Self-interest or Political Ideology? A Longitudinal Approach.” Acta Sociologica 49 (3): 321-338. doi: 10.1177/0001699306067718.

Jensen, P. H., and H. Lolle. 2013. “The Fragmented Welfare State: Explaining Local Variations in Services for Older People.” Journal of Social Policy 42 (2): 349-370. doi: $10.1017 /$ S0047279412001006.

Johansson, O. 2011. Tjäna eller tjäna? Om vård eller vinst. [Serve or earn? On care or profit]. Stockholm: Famna.

Johansson Sevä, I. 2009. Welfare State Attitudes in Context: Local Contexts and Attitude Formation in Sweden. Umeå: Umeå University.

Johansson Sevä, I. 2010. “Suspicious Minds: Local Context and Attitude Variation across Swedish Municipalities.” International Journal of Social Welfare 19 (2): 225-235. doi: 10.1111/j.1468-2397.2009.00656.x. 
Kettl D.F. 1993. Sharing Power: Public Governance and Private Markets. Washington DC: Brookings Institution Press.

Konkurrensverket (2013). Kommunernas valfrihetssystem - med fokus på hemtjänst [Local government system of choice - with a focus on home care]. Stockholm: Slutrapport.

Lindbom, A. 2014. “Waking Up the Giant? Hospital Closures and Electoral Punishment in Sweden”, p. 156-180. In Staffan Kumlin and Isabelle Stadelmann-Steffen (eds), How Welfare States Shape the Democratic Public. Cheltenham, Edward Elgar.

Lindbom, A. 2016. "Political Partisanship and Policy Feedback: The Swedish Welfare State after Eight Years of Center-Right Government”, p. 37-56. In Jon Pierre (ed), The Oxford Handbook of Swedish Politics. Oxford, Oxford University Press.

Mair, P. 2007. “Left-Right Orientations.” In The Oxford Handbook of Political Behaviour, edited by J. D. Russell and H.D. Klingemann, 206-222. Oxford: Oxford University Press.

Manning, N. 2001. “The legacy of the New Public Management in developing countries.” International Review of Administrative Sciences (67), no. 2: 297-312.

Meagher, G., and M. Szebehely. 2013. Marketisation in Nordic Eldercare: A Research Report on Legislation, Oversight, Extent and Consequences. Stockholm: Stockholm University.

Megginson, W.L., and J.M. Netter. 2001. "From State to Market: A Survey of Empirical Studies on Privatization.” Journal of Economic Literature 39 (2). American Economic Association: 321-389.

National Board of Health and Welfare (NBHW). 2007. Current Developments in Care of the Elderly in Sweden. Stockholm: Socialstyrelsen. 
National Board of Health and Welfare (NBHW). 2014. Äldre och personer med funktionsnedsättning - regiform år 2013 - Vissa kommunala insatser enligt socialtjänstlagen, (Older and disabled persons-management forms, 2013). Stockholm: Socialstyrelsen.

Norris, P. 1995. “May’s Law of Curvilinear Disparity Revisited: Leaders, Officers, Members and Voters in British Political Parties.” Party Politics, 1(1), 29-47.

Ormerod, R. 2006. “The History and Ideas of Pragmatism.” The Journal of the Operational Research Society, 57 (8): 892-909.

Pierson, P. 1994. Dismantling the Welfare State?: Reagan, Thatcher and the Politics of Retrenchment. Cambridge: Cambridge University Press.

Pierson, P. 1996. “The new politics of the welfare state.” World Politics, 48(2), 143-179.

Pierson, P. (Ed.). 2001. The New Politics of the Welfare State. Oxford: Oxford University Press.

Rothstein, B. 1998. Just Institutions Matter: The Moral and Political Logic of the Universal Welfare State. Cambridge: Cambridge University Press.

Savas, E. 2000. Privatisation and Public-Private Partnerships. New York: Chatham House.

Søren, S. 2003. “Shaping Local Councillor Preferences: Party Politics, Committee Structure and Social Background.” Scandinavian Political Studies, 26(4), 327-348. doi:10.1111/j.1467-9477.2003.00092.x

Sørensen, R., and A. H. Bay. 2002. “Competitive Tendering in the Welfare State: Perceptions and Preferences among Local Politicians.” Scandinavian Political Studies 25 (4): 357-384.

Statistics Sweden (SCB). 2015a. “Antal invånare per kvadratkilometer, 31 december 2014.” (Number of inhabitants per square kilometre) http://www.scb.se/sv_/Hitta- 
statistik/Statistik-efter-amne/Befolkning/Befolkningens-

sammansattning/Befolkningsstatistik/25788/25795/Topplistor-kommuner/290734/

Statistics Sweden (SCB). 2015b. "Skatteunderlag per invånare (skattekraft) kommunvis, taxeringsåret 2014.” (Tax base per inhabitant by municipality in the year 2014) http://www.scb.se/sv_/Hitta-statistik/Statistik-efter-amne/Offentligekonomi/Finanser-for-den-kommunalasektorn/Kommunalskatterna/11849/11856/67865/

Stolt, R., and U. Winblad. 2009. "Mechanisms behind Privatization: A Case Study of Private Growth in Swedish Elderly Care.” Social Science \& Medicine 68 (5): 903-911. doi: 10.1016/j.socscimed.2008.12.011.

Svallfors, S. 1989. Vem älskar välfärdsstaten?: attityder, organiserade intressen och svensk välfärdspolitik [Who Loves the Welfare State? Attitudes, Organized Interests and Swedish Welfare Policies]. Arkiv avhandlingsserie: 30. Lund: Arkiv.

Svallfors, S. 1999. Mellan risk och tilltro: Opinionsstödet för en kollektiv välfärdspolitik [Between Risk and Confidence: Popular Support for Collective Welfare Policies]. Umeå: Umeå Studies in Sociology.

Svallfors, S. 2004. "Class, attitudes and the Welfare State: Sweden in comparative perspective”. Social Policy \& Administration, 38(2), 119-138.

Sveriges Kommuner och Landsting (SKL). 2015. "Sammanställning styren i kommuner och landsting 1994 tom 2014.” http://skl.se/download/18.44c045bc14d99500c85105f8/1433176992847/sklmaktfordelning-kommuner-landsting-regioner-1994-2014-reviserad-2015-06-01.xlsx

Szebehely, M. 2011. "Insatser för äldre och funktionshindrade i privat regi” [Caring for elderly and disabled people in private enterprises]. In: Konkurrensens konsekvenser: 
Vad händer med svensk välfärd? [The Consequences of Competition. What is happening to Swedish Welfare?], edited by L. Hartman, 215-257, Stockholm: SNS.

Warner, M., and R. Gradus. 2011. The Consequences of Implementing a Child Care Voucher Scheme: Evidence from Australia, the Netherlands and the USA. Social Policy \& Administration;45(5):569-592.

Warner, M., and A. Hefetz. 2012. "Insourcing and Outsourcing,” Journal of the American Planning Association, 78:3, 313-327.

Weaver, R. K. 1986. “The Politics of Blame Avoidance.” Journal of Public Policy 6 (4): 371-398.

Young, S. 2000. “Outsourcing: lessons from the literature.” Labour and Industry, 10 (3): 97117.

Zaller, J. 1992. The Nature and Origins of Mass Opinion. Cambridge: Cambridge University Press. 


\section{Appendix 1:}

Table A1: Summary statistics of survey respondents

\begin{tabular}{|c|c|c|c|c|}
\hline & & Frequency & Percent & $\begin{array}{r}\text { Cumulative } \\
\text { Percent } \\
\end{array}$ \\
\hline \multirow[t]{3}{*}{ Gender } & Female & 736 & 54.0 & 54.0 \\
\hline & Male & 623 & 45.7 & 99.8 \\
\hline & Neutral & 3 & 0.2 & 100.0 \\
\hline \multicolumn{5}{|l|}{ Age } \\
\hline & $18-29$ & 41 & 3.0 & 3.0 \\
\hline & $30-39$ & 106 & 7.8 & 10.8 \\
\hline & $40-49$ & 183 & 13.4 & 24.2 \\
\hline & $50-64$ & 549 & 40.3 & 64.5 \\
\hline & 65 and above & 483 & 35.5 & 100.0 \\
\hline \multicolumn{5}{|l|}{ Term } \\
\hline & This mandate & 469 & 4.4 & 34.4 \\
\hline & 2 terms & 282 & 20.7 & 55.1 \\
\hline & 3 terms & 212 & 15.6 & 70.7 \\
\hline & 4 or more terms & 399 & 29.3 & 100.0 \\
\hline \multicolumn{5}{|l|}{ Position } \\
\hline & $\begin{array}{l}\text { Local government } \\
\text { commissioner }\end{array}$ & 160 & 11.8 & 11.8 \\
\hline & Chairperson & 233 & 17.1 & 28.9 \\
\hline & Ordinary member & & & 100.0 \\
\hline & & 969 & & 71.1 \\
\hline & Total & 1,362 & 100 & 100 \\
\hline
\end{tabular}


Appendix 2: Survey questions used:

1. Do you think that there should be more or less public elderly care in the municipality?
o Much more
o Somewhat more
o Satisfied with the present situation
o Somewhat less
o Much less
o Do not know, prefer to not take a position

2. Do you think that there should be more or less private elderly care in the municipality?

o Much more

o Somewhat more

o Satisfied with the present situation

o Somewhat less

o Much less

o Do not know, prefer to not take a position

3. What do you think an optimum distribution would be regarding the various forms of elderly care (please state in \%)?

Public $\quad$, Private for-profit $\quad$, Private non-profit 
Table 1. Regression variables and data source

\begin{tabular}{|c|c|c|}
\hline & Measures & Sources \\
\hline \multicolumn{3}{|l|}{ Dependent variables } \\
\hline \multirow[t]{2}{*}{ Preferences for privatisation in home municipality } & 1: Much less; 2: Slightly less; & Questionnaire \\
\hline & 3: Good as it is; 4: Slightly more; 5: Much more & \\
\hline $\begin{array}{l}\text { Optimum share of private for-profit/nonprofit/public provision } \\
\text { in elderly care }\end{array}$ & $0-100 \%$ & Questionnaire \\
\hline \multicolumn{3}{|l|}{ Independent variables } \\
\hline Political Orientation & 0: Left-wing; 1: Right-wing & Questionnaire \\
\hline Gender & 0: Women; 1: Men & Questionnaire \\
\hline Age & $0:<50$ years; $1:>50$ years & Questionnaire \\
\hline Political position & $\begin{array}{l}\text { 0: ordinary members; } 1 \text { : chairperson } \\
\text { 2: municipal commissioner }\end{array}$ & Questionnaire \\
\hline \multirow{2}{*}{ Term } & 1: this term; 2: 2 terms; & Questionnaire \\
\hline & 3: 3 terms; 4: 4 terms or more & \\
\hline Privatisation level index & $0-100 \%$ & NBHW (2014) \\
\hline Political majority spring 2014 & -1: left-wing 0: mixed 1: right-wing & SKL (2015) \\
\hline \multicolumn{3}{|l|}{ Population (in Log) } \\
\hline \multicolumn{3}{|l|}{ Population density } \\
\hline Taxation power (in 1,000 SEK) & Basis of tax assessment per capita 2014 & SCB (2015 b) \\
\hline
\end{tabular}


Table 2. Response rate (\%) for different parties when asking: Do you want more or less private elderly care in your municipality?

Slightly or much Good as it is Slightly or much less

more

\begin{tabular}{|c|c|c|c|}
\hline Left wing bloc (589) & 2 & 40 & 58 \\
\hline Left Party (89) & 2 & 16 & 82 \\
\hline $\begin{array}{l}\text { Social Democratic P. } \\
(413)\end{array}$ & 1 & 44 & 55 \\
\hline Green Party (87) & 9 & 46 & 45 \\
\hline Right wing bloc (667) & 70 & 27 & 2 \\
\hline Centre Party (154) & 66 & 31 & 3 \\
\hline $\begin{array}{l}\text { Liberal People’s Party } \\
\text { (129) }\end{array}$ & 64 & 32 & 5 \\
\hline Christian Democrats (75) & 69 & 28 & 2 \\
\hline Moderate Party (309) & 76 & 24 & 1 \\
\hline
\end{tabular}


Table 3. Preferences for public and private providers in municipal elderly care as a percentage

For profit Non profit Public

\begin{tabular}{lccc} 
Right-centre bloc (360) & 30.76 & 19.87 & 49.37 \\
Centre Party (81) & 21.7 & 19.38 & 58.92 \\
Liberals (78) & 29.78 & 19.6 & 50.62 \\
Christian Dem. (40) & 26.05 & 25.4 & 48.55 \\
Moderate Party (161) & 36.96 & 18.86 & 44.18 \\
Left-green bloc (430) & 1.23 & 13.33 & 85.44 \\
Green Party (67) & 3.36 & 23.13 & 73.51 \\
Social Democrats (296) & 1.03 & 11.71 & 87.26 \\
Left Party (67) & 0 & 10.38 & 89.62 \\
\hline
\end{tabular}


Table 4. Binary logistic regression of private provider preference

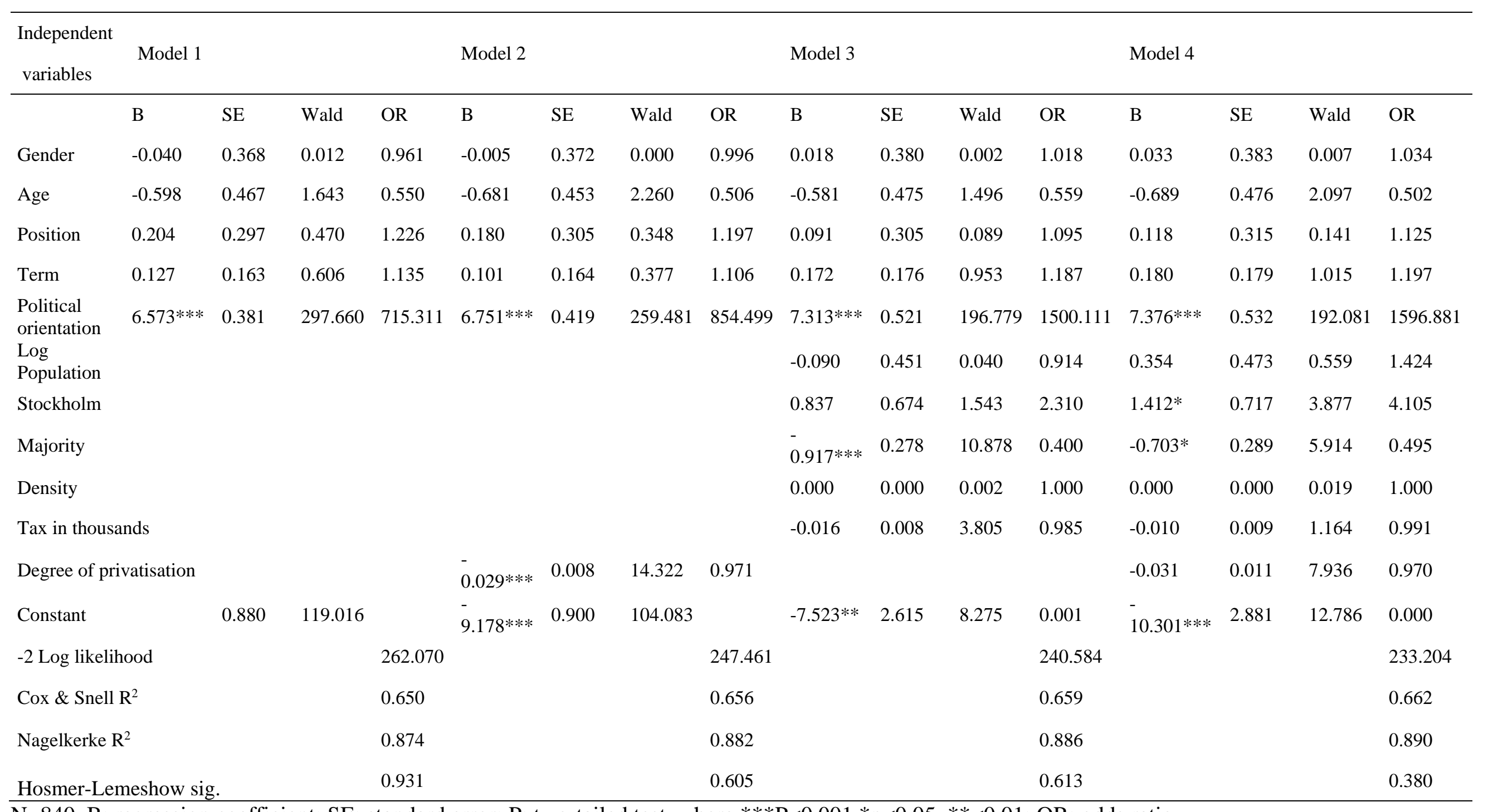

$\mathrm{N}=840$. B: regression coefficient; SE: standard error; P: two-tailed test, where ${ }^{* * *} \mathrm{P}<0.001,{ }^{*} \mathrm{p}<0.05,{ }^{* *}<0.01$; OR: odds ratio. 
Table 5. Regression analysis of optimum share of various types of care providers

\begin{tabular}{|c|c|c|c|}
\hline Parameter & For-profit & Non-profit & Public \\
\hline \multirow[t]{2}{*}{ Constant } & -4.210 & 5.059 & $93.400 * * *$ \\
\hline & $(0.233)$ & $(0.340)$ & $(105.522)$ \\
\hline \multirow[t]{2}{*}{ Political Orientation } & $29.502 * * *$ & $6.197 * * *$ & $-35.213 * * *$ \\
\hline & $(560.431)$ & $(27.066)$ & (1021.003) \\
\hline \multirow[t]{2}{*}{ Gender } & $3.749 * *$ & $-3.637 * *$ & 0.303 \\
\hline & (11.041) & $(10.040)$ & $(0.077)$ \\
\hline \multirow[t]{2}{*}{ Age } & $-3.066^{*}$ & -1.245 & $3.174 *$ \\
\hline & $(5.071)$ & $(0.769)$ & $(6.480)$ \\
\hline \multirow[t]{2}{*}{ Position } & 1.090 & -1.656 & 1.111 \\
\hline & $(1.721)$ & $(3.474)$ & $(1.862)$ \\
\hline \multirow[t]{2}{*}{ Period } & -0.094 & -0.362 & 0.709 \\
\hline & $(0.041)$ & $(0.496)$ & $(2.428)$ \\
\hline \multirow[t]{2}{*}{ Privatisation } & $0.255^{* * *}$ & 0.009 & $-0.249 * * *$ \\
\hline & (24.948) & $(0.053)$ & $(34.402)$ \\
\hline \multirow[t]{2}{*}{ Logpop } & 1.022 & 2.229 & $-2.914^{*}$ \\
\hline & $(0.567)$ & $(2.573)$ & $(4.842)$ \\
\hline \multirow[t]{2}{*}{ Majority } & $-2.182 * *$ & 0.521 & $1.593 *$ \\
\hline & (10.353) & $(0.510)$ & $(5.318)$ \\
\hline \multirow[t]{2}{*}{ Stockholm } & -0.872 & $6.041 *$ & $-4.541 *$ \\
\hline & $(0.135)$ & $(7.004)$ & $(4.107)$ \\
\hline \multirow[t]{2}{*}{ Population density } & $0.000 * *$ & $-0.001^{*}$ & $0.001 *$ \\
\hline & $(0.354)$ & $(4.245)$ & $(3.860)$ \\
\hline \multirow{2}{*}{$\begin{array}{l}\text { Taxation power (in } \\
1,000 \text { SEK) }\end{array}$} & 0.017 & 0.008 & 0.026 \\
\hline & $(0.159)$ & $(0.049)$ & $(0.291)$ \\
\hline $\mathrm{R}^{2}$ & 0.568 & 0.082 & 0.509 \\
\hline $\mathrm{N}$ & 790 & 790 & 910 \\
\hline
\end{tabular}

The Wald Chi-square test results are reported in parentheses. ${ }^{* * *} \mathrm{p}<0.001 ;{ }^{* *} \mathrm{p}<0.01$; ${ }^{*} \mathrm{p}<0.05$ 